\title{
VACCARIA HISPANICA (CARYOPHYLLACEAE) REDISCOVERED IN POLAND
}

\author{
Karol Torzewski, Aleksandra Kazienko, Arkadiusz Drapiewski, Tomasz Sienkiewicz
}

\begin{abstract}
A. Drapiewski, Wroclaw Medical University, Ludwika Pasteura 1, 50-367 Wrocław, Poland, e-mail: arkadiusz.drapiewski@gmail.com

A. Kazienko, Department of Ecology, Biogeochemistry and Environmental Protection, University of Wrocław, Kanonia 6/8, 50-328 Wrocław, Poland, e-mail: aleksandra.kazienko@uwr.edu.pl

T. Sienkiewicz, Department of Evolutionary Biology and Conservation of Vertebrates, University of Wrocław, Sienkiewicza 21, 50-335 Wrocław, Poland, e-mail: tomasz.sienkiewicz@uwr.edu.pl

K. Torzewski, Department of Ecology, Biogeochemistry and Environmental Protection, University of Wrocław, Kanonia 6/8, 50-328 Wrocław, Poland, e-mail: karol.torzewski@uwr.edu.pl (corresponding author).
\end{abstract}

(Received: October 5, 2018. Accepted: October 30, 2018)

\begin{abstract}
Vaccaria hispanica, due to the lack of statements in recent years in Poland, was considered extinct. It was rediscovered in the agricultural areas of Wrocław between Domaszczyn and Zakrzów. Plant communities with $V$. hispanica were classified into the Stellarietea mediae class and the Artemisietea vulgaris class. All collected soil samples were characterized by slightly acidic soil $\mathrm{pH}$ between 6,4-6,7. Based on the results, we suggest changing the status of $V$. hispanica in the Polish red list and the red book from "extinct" to "critically endangered".
\end{abstract}

KeY words: Vaccaria hispanica, endangered species, distribution, habitat, Caryophyllaceae, Poland

\section{INTRODUCTION}

Vaccaria hispanica (Mill.) is a species most likely native of the Mediterranean region, from where it was further spread widely in the rest of Europe and further to Asia (CONERT 1979). It has also been dragged to North America, South America, South Africa, New Zealand and Australia (KästNer et al. 2001). In addition to the typical taxon Vaccaria hispanica ssp. hispani$c a$, there is also $V$. hispanica var. grandiflora with petals up to 18-23 mm long (Euíšs 2006), however, both subspecies are not geographically diverse (CONERT 1979). The cow cockle is a thermophilic species that prefers soils rich in calcium compounds. It was noted on arable fields and balks. Vaccaria hispanica is considered as a species characteristic for cereal crops on limestone soils of the Caucalidion lappulae association (Matuszkiewicz 2005). This species was also found in ports, on roadsides, on railway grounds and near grain elevators (SzCZĘŚNIAK 2011).
In Poland, the species is widespread, with two distinct clusters in south-western Poland, especially in Lower Silesia and in eastern Poland, mainly in the Lublin Upland, Roztocze and Polesie (ZająC \& ZająC 2001, WĘGRZYNEK 2014). Polish populations were limited to a few individuals or, as in Lower Silesia, described as mass (SZCZĘŚNIAK 2011, WĘGRZYNEK 2014).

Despite the wide range of $V$. hispanica, the species has been withdrawing from all over Europe in recent years. It was considered, probably extinct in the Czech Republic (KROPÁč 2006), critically endangered in Austria (Niklfeld \& Schratt-Ehrendorfer 1999), critically endangered in Slovakia (Eliáš et al. 2005) threatened in Hungary (KIRÁLY 2007), endangered in Croatia (Hulina 2005). In Poland, due to the lack of observation in recent years, it was considered extinct (WęGRZYNeK 2014 - EX category, KaźmIERCZAKOWA et al. 2016 - category RE).

The reasons for the disappearance of $V$. hispanica from Poland are not fully known, most probably due 
to the introduction of modern agrotechnical methods, especially chemical weed control, the introduction of fast growing varieties and effective seed treatment (WĘGRZYNEK 2014). In Lower Silesia, V. hispanica probably disappeared as a result of seed exchange after 1945, which was related to the population exchange of this area after World War II (SZCZĘŚNIAK 2011).

\section{MATERIAL AND METHODS}

Floristic observations were conducted from June to September 2018. For the documentation, phytosociological relevés were taken according to the Braun-Blanquet method (BARKMAN et al. 1964). The nomenclature of vascular plants was adopted according to MireK et al. (2002), phytosociological classifications were based on the study of MatuszKiEwicz (2005). The current position of the species in Poland is expressed in a square system of the ATPOL (ZAJĄC 1978), additionally GPS coordinates (Garmin 62sc) were registered. For IUCN Red List Categories and Criteria were used (IUCN STANDARDS... 2016).

During the research, the soil samples were collected at one time to measure soil $\mathrm{pH}$. Topsoil samples
(0-10 cm depth) were collected in three replicates from each site. The $\mathrm{pH}$ was determined using the potentiometric method by soaking $1 \mathrm{~g}$ of soil samples in vials with $10 \mathrm{ml}$ deionised water. The vials were stoppered and left overnight. The mixtures were vacuum filtered through washed paper filters. The $\mathrm{pH}$ of the filtrates was determined by pH-meter CP-105 (Elmetron, Poland).

\section{RESULTS AND DISCUSSION}

Vaccaria hispanica ssp. hispanica was found in the agricultural areas of the Mirków village, between Domaszczyn and Zakrzów in the south-western part of Poland. The stand is located in the ATPOL CE40 square (Fig. 1). The $V$. hispanica population is scattered over an area of 1 ha, creating smaller groups in places. In total, 36 flowering plants were recorded, including 15 which later bound the plant stems (Fig. 2).

Vaccaria hispanica occupies the margins of cereal crops and sugar beets reminiscent of the plant communities from the Stellarietea mediae class. In addition, part of the largest population was found in

Table 1. Relevé with Vaccaria hispanica ssp. hispanica and $\mathrm{pH}$ from the studied populations

\begin{tabular}{|c|c|c|c|c|}
\hline Relevé number & 1 & 2 & 3 & 4 \\
\hline Relevé area $\left(\mathrm{m}^{2}\right)$ & $25 \mathrm{~m}^{2}$ & $25 \mathrm{~m}^{2}$ & $25 \mathrm{~m}^{2}$ & $25 \mathrm{~m}^{2}$ \\
\hline Date & 10.08.2018 & 10.08.2018 & 10.08 .2018 & 05.10 .2018 \\
\hline Latidude $\mathrm{N}$ & $51^{\circ} 09^{\prime} 49.4^{\prime \prime}$ & $51^{\circ} 10^{\prime} 06.9^{\prime \prime}$ & $51^{\circ} 10^{\prime} 12.1^{\prime \prime}$ & $51^{\circ} 10^{\prime} 23.5^{\prime \prime}$ \\
\hline Longitude E & $17^{\circ} 08^{\prime} 34.2^{\prime \prime}$ & $17^{\circ} 08^{\prime} 42.2^{\prime \prime}$ & $17^{\circ} 08^{\prime} 44.5^{\prime \prime}$ & $17^{\circ} 09^{\prime} 20.6^{\prime \prime}$ \\
\hline $\mathrm{pH}$ & 6.7 & 6.4 & 6.4 & 6.5 \\
\hline Herb cover $(\%)$ & 70 & 60 & 40 & 40 \\
\hline \multicolumn{5}{|c|}{ I. ChCl. Stellarietea mediae } \\
\hline Setaria viridis & + & 2 & 1 & 1 \\
\hline Apera spica-venti & 2 & 1 & 1 & . \\
\hline Echinochloa crus-galli & 2 & 1 & 1 & . \\
\hline Matricaria chamomilla & 2 & 1 & 1 & . \\
\hline Fallopia convolvulus & 1 & + & + & . \\
\hline Centaurea cyanus & 1 & + & $\mathrm{r}$ & . \\
\hline Anagallis arvensis & 1 & + & . & . \\
\hline Vaccaria hispanica ssp. hispanica & $\mathrm{r}$ & + & + & + \\
\hline Viola arvensis & + & $\mathrm{r}$ & . & . \\
\hline Polygonum aviculare & + & . & . & . \\
\hline Anchusa arvensis & $\mathrm{r}$ & . & . & . \\
\hline \multicolumn{5}{|c|}{ II. ChCl. Artemisietea vulgaris } \\
\hline Chenopodium album & . & . & . & 2 \\
\hline Echium vulgare & . & . & . & + \\
\hline Hypericum perforatum & . & . & . & + \\
\hline Solidago gigantea & $\mathrm{r}$ & . & . & . \\
\hline \multicolumn{5}{|c|}{ III. Others } \\
\hline Beta vulgaris ssp. vulgaris var. altissima & . & . & 3 & . \\
\hline Secale cereale & 1 & 2 & . & . \\
\hline Elymus repens & . & . & . & 1 \\
\hline Plantago lanceolata & . & . & . & + \\
\hline Plantago major & + & . & . & . \\
\hline Erodium cicutarium & . & . & . & $\mathrm{r}$ \\
\hline Panicum barbipulvinatum & . & . & . & $\mathrm{r}$ \\
\hline
\end{tabular}




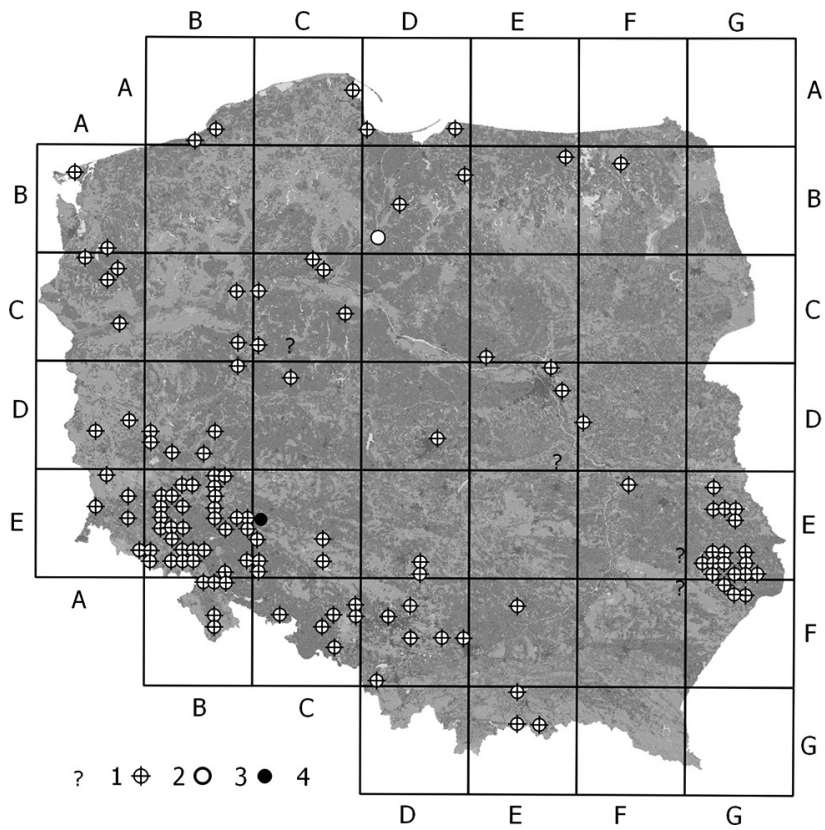

Fig. 1. Distribution of Vaccaria hispanica ssp. hispanica in Poland (according to WĘGRZYNEK 2014; supplemented) 1 - doubtful position, 2 - historical position, 3 - unconfirmed position, $4-$ new position.

ruderal communities reminiscent of the Artemisietea vulgaris class. The phytosociological characteristics of occupied plant communities are represented by the following four phytosociological relevés. All collected soil samples were characterized by slightly acidic soil $\mathrm{pH}$ between 6,4-6,7 (Table 1).

The newly discovered $V$. hispanica population in Wrocław is currently the only known one in Poland. It is located about $10 \mathrm{~km}$ from the last quotation from this area in the district of Wrocław-Krzyki (RosTAŃSKI 1961, SZCZĘ́ŚNIAK 2011).

In spite of intensive searches in the adjacent areas, no other populations were found. During the inspections carried out in the summer of 2018, the flowering was confirmed in August and September, which was caused by the cutting of the shoots by agricultural machines. Despite the late flowering, part of the $V$.

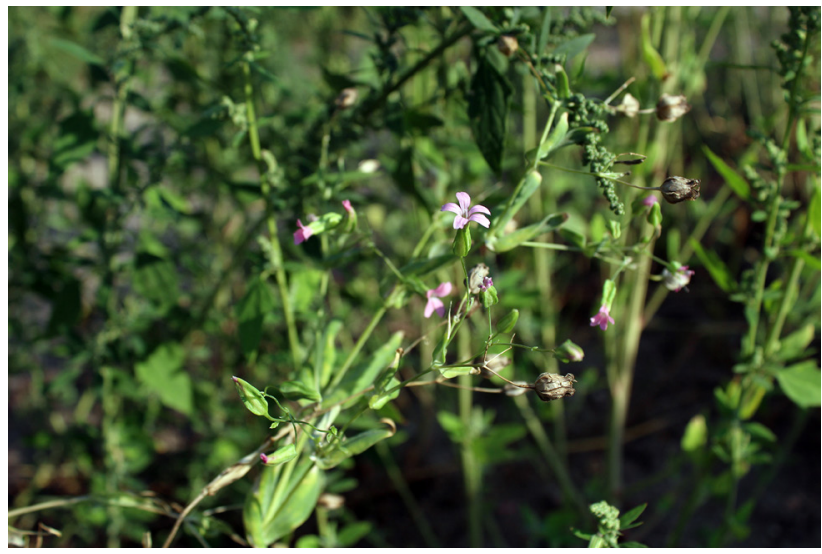

Fig. 2. Flowering Vaccaria hispanica ssp. hispanica, Mirków, 5.10.2018 (photo: K. Torzewski) hispanica specimens formed seeds. The main threat to the found populations is the intensification of agriculture, especially the chemical control of weeds and change of physical and chemical properties of soils. This would indicate the occupation of non-herbicide borders. It also seems that this alkaline species has adapted to a neutral $\mathrm{pH}$ of the soil. It is therefore necessary to conduct further observations of the examined position. The active protection in situ conditions can be helpful in protecting this species.

Based on the results and classification of the IUCN, we propose to change the status of $V$. hispanica in the Polish red list (category - RE) and in the red book (category - EX) changing the category from "extinct" to "critically endangered" - CR.

\section{REFERENCES}

Barkmann J.J., Doing H., Segal S. (1964): Kritische Bemerkungen und Vorschläge zur quantitativen Vegetationsanalyse. Acta Botanica Neerlandica 13: 394-419.

Conert H. (1979): Vaccaria Wolf. In: G. Hegi, Illustrierte Flora von Mitteleuropa 3. Paul Parey Verlag, Hamburg-Berlin: 977--978.

Eliáš P. JUn. (2006): Contributions to the taxonomy and distribution of Cow cockle (Vaccaria hispanica) in Slovakia. Acta Fytotechnica et Zootechnica 4(9): 96-99.

Eliáš P. Jun., Eliáš P. SEN., Baranec T. (2005): The new red list of Slovak endangered weeds. In: P. Eliáš jun. (ed.). Threatened weedy plant species. Book of proceedings from the international conference. Slovak University of Agriculture, Nitra: 23-28.

Hulina N. (2005): List of threatened weeds in the continental part of Croatia and their possible conservation. Agriculturae Conspectus Scientificus 70(2): 37-42.

IUCN Standards and Petitions Subcommittee. (2017). Guidelines for Using the IUCN Red List Categories and Criteria. Version 13. http://www. iucnredlist.org/documents/RedListGuidelines. pdf (access: 13.09.2018).

KästNer A., JäGer E.J., Schubert R. (2001): Handbuch der Segetalpflanzen Mitteleuropas. Springer, Wien, New York.

Kaźmierczakowa R., Bloch-Orfowska J., Celka Z., Cwener A., Dajdok Z., Michalska-Hejduk D., PaWlikowski P., SZCZĘ́́niak E., Ziarnek K. (2016): Polish red list of pteridophytes and flowering plants. Instytut Ochrony Przyrody Polskiej Akademii Nauk, Kraków.

KirÁLY G. (2007): Red list of the vascular flora of Hungary. Sopron, Hungary.

KROPÁč Z. (2006): Segetal vegetation in the Czech Republic: synthesis and syntaxonomical revision. Preslia 78(2) 123-210. 
Matuszkiewicz W. (2005): Przewodnik do oznaczania zbiorowisk roślinnych Polski. Wydawnictwo Naukowe PWN, Warszawa.

Mirek Z., Pię́Koś-Mirkowa H., Zając A., Zając M. (2002): Flowering plants and pteridophytes of Poland. A checklist. In: Z. Mirek (ed.). Biodiversity of Poland, 1. W. Szafer Institute of Botany, Polish Academy of Sciences, Kraków.

Niklfeld H., Schratt-Ehrendorfer L. (1999): Rote Liste gefährdeter Farn- und Blütenpflanzen (Pteridophyta und Spermatophyta) Österreichs. 2. Fassung. In: H. NiKLfeld H. (ed.). Rote Listen gefährdeter Pflanzen Österreichs. Grüne Reihe des Bundesministeriums für Umwelt, Jugend und Familie 10: 33-151.

RostaŃsKI K. (1961): Interesujące gatunki synantropijne $z$ terenu miasta Wrocławia. Część 2. Fragmenta Floristica et Geobotanica 7(2): 291-298.

SzCZĘŚNIAK E. (2011): Vaccaria hispanica (Caryophyllaceae) - an extinct species in Lower Silesia. Acta Botanica Silesiaca, Supplementum 1: 210-212.
WĘGRZYNEK B. (2014): Vaccaria hispanica (Mill.) Rauschert. Krowiziół zbożowy. In: R. Kaźmierczakowa, K. Zarzycki, Z. Mirek (eds). Polska czerwona księga roślin. Paprotniki i rośliny kwiatowe. Instytut Ochrony Przyrody, Polska Akademia Nauk, Kraków: 143-146.

ZajĄC A., ZajĄC M. (ed.) (2001): Atlas rozmieszczenia roślin naczyniowych w Polsce. Pracownia Chorologii Komputerowej, Instytut Botaniki Uniwersytetu Jagiellońskiego, Kraków.

ZAJĄC A. (1978): Założenia metodyczne „Atlasu rozmieszczenia roślin naczyniowych w Polsce". Wiadomości Botaniczne 22(3): 145-155.

For citation: Torzewski K., Kazienko A., DraPIEWSKI A., SIENKIEwICZ T. (2018): Vaccaria hispanica (Caryophyllaceae) rediscovered in Poland. Steciana 22, 4: 129-132. doi: 10.12657/steciana.022.015 